\title{
THE POLISH-LITHUANIAN CRISIS OF MARCH 1938. SOME ROMANIAN AND WESTERN REACTIONS
}

\section{Bogdan Schipor}

"A.D. Xenopol" Institute of History of the Romanian Academy, E-mail: bogdan_schipor@yahoo.it

This paper has been presented at the First International Conference on Nordic and Baltic Studies in Romania: Romania and Lithuania in the Interwar International Relations: Bonds, Intersections and Encounters hosted by the Romanian Association for Baltic and Nordic Studies, Târgoviste, May 19-21, 2010.

\begin{abstract}
:
In March 1938, when the eyes of the entire Europe were trained on the events in Austria that culminated with the Anschluss, there was another conflict on the European continent that bothered the Western powers, and not only. On March 17, 1938 the Polish minister at Tallinn handed to the Lithuanian minister in the capital of Estonia a notification through which Warsaw asked Lithuania to establish immediate diplomatic relations without prior conditions. The Polish government considered this the only way to solve the problems related to the border between the two states without jeopardizing the peace. Lithuania had 48 hours after the delivery of the notification to accept the proposal without any debate or negotiation. Its rejection would have given Warsaw the right to ensure its objectives and interests by any means it deemed necessary. Great Britain and France reacted cautiously to this new crisis, hoping for a peaceful solution, in order to avoid the involvement of the League of Nations or the escalation of the events towards an open conflict between the two states. In its turn, Romania, as an ally of Poland, refrained from a possible involvement or condemnation of Warsaw's actions, a fact for which the Polish diplomats expressed their gratitude. But even if Lithuania conceded and the crisis died out, the Western countries, as well as Romania, had certain anxieties raised by the Polish-Lithuanian crisis which were to come true a year later. Poland's actions in March 1938 had created a precedent that other powers did not hesitate to follow and the country that, in the end, would lose everything was Poland itself.
\end{abstract}

\section{Rezumat:}

In momentul $\hat{\imath}$ care $\hat{\imath}$ martie 1938 privirile întregii Europe erau ațintiți asupra evenimentelor din Austria care au culminat cu realizarea Anschlussului, a mai existat un conflict pe continentul european care a nemultumit puterile occidentale, şi nu numai. La 17 martie 1938 ministrul polonez la Tallinn i-aînmânat 
omologului său lituanian o notă prin care Varşovia solicita Lituaniei stabilirea imediată de relațiile diplomatice fără nicio condiție prealabilă. Guvernul polonez a considerat aceasta singura cale de a rezolva problemele legate de frontiera dintre cele două state fără a pune pacea în pericol. Lituania avea la dispoziție numai 48 de ore de la transmiterea notei pentru a accepta propunerea fără nicio discuție sau negociere. Respingerea sa ar fi dat Varşoviei dreptul de a-şi asigura obiectivele şi interesele prin orice mijloace pe care le considera necesare. Marea Britanie şi Franța au reactionat cu prudență cu privire la această nouă criză, sperând într-o soluție paşnică, în scopul de a evita implicarea Societății Națiunilor sau escaladarea evenimentelor în direcția unui conflict deschis între cele două state. La rândul său, România, aliată a Poloniei, s-a abținut de la orice implicare sau condamnare a acțiunilor Varşoviei, poziție pentru care diplomații polonezi şi-au exprimat gratitudinea. Dar chiar dacă Lituania a cedat şi criza a încetat, țările occidentale, la fel ca şi România, au nutrit anumite nelinişti alimentate de criza polonezo-lituaniană, care se vor adeveri un an mai târziu. Acțiunile Poloniei din martie 1938 au creat un precedent pe care alte puteri nu vor ezita să-l urmeze, iar tara care, in final, va pierde totul va fi chiar Polonia.

Keywords: Poland, Lithuania, ultimatum, international crisis, Romania, Western Europe

After a rapid succession of political events in 1935-1936, 1937 was a relatively quiet year in Europe, with the rather isolated exception of the Spanish civil war. But things were about to change completely a year later, in 1938, which bore the mark, first of all, of two events that anticipated the evolution of European politics towards a great conflict: the Anschluss and the Sudeten crisis.

The Germans seemed prepared in the spring of 1938 to modify the national borders as established by the Treaty of Versailles. Thus, after they made certain of enlisting the support of Italy and the neutrality of Poland, on March 12, 1938, after a whole month of tensions and threats, the German troops crossed the border with Austria almost immediately after Berlin had addressed Vienna an ultimatum ${ }^{2}$. The fact that, the day before, Great Britain had objected in most categorical terms against the German ultimatum and against the threat of using force if the requests made by

1 Emilian Bold and Ioan Ciupercă, Europa în derivă (1918-1940). Din istoria relațiilor internationale [Europe Adrift (1918-1940). From the History of International Relations] (Iaşi: Demiurg Publishing House, 2001), 196.

2 Henry Kissinger, Diplomația [Diplomacy], Trans. Mircea Ştefancu and Radu Paraschivescu (Bucharest: All Publishing House, 1998), 282. 
Berlin were not satisfied at once, had no effect ${ }^{3}$. In spite of having generated a profound concern in the countries of Eastern and Central Europe, the German action in Austria determined nothing else but protests and indignation in Great Britain, even if the final events of the Austrian crisis and Berlin's enforcement of the Anschluss took Europe by surprise ${ }^{4}$. As for the rest, nothing had changed. The British government did not even consider bringing into discussion the events in Austria before the League of Nations, reasoning that such a gesture would be completely useless 5 . This time the French agreed with the British. In their turn, they also thought that to put into motion the bureaucratic apparatus of the League would have been pointless 6 .

Coincidence or not ${ }^{7}$, during the crisis in Austria, there was another conflict in Europe that bothered the Western powers. On March 17, 1938, the Polish minister at Tallinn handed to the Lithuanian minister in the capital of Estonia a notification through which Warsaw asked Lithuania to establish immediate diplomatic relations without prior conditions. The Polish government considered this the only way to solve the problems related to the border between the two states without jeopardizing the peace. Lithuania had 48 hours after the notification was delivered to accept the proposal, and the mutual accreditation of diplomats had to take place until March 31, 1938 at the latest. The Polish proposal was not open for debate or negotiations and its rejection would have given Warsaw the right to ensure its objectives and interests by any means it deemed necessary ${ }^{8}$. Moreover, the Poles asked the Lithuanian government to open a railroad immediately and to resume the postal relations between the two countries, to reach a mutual understanding regarding the issues related to minorities, to sign a trade and customs agreement, to revoke the articles in the

\footnotetext{
3 E.L. Woodward and Rohan Butler, eds., Documents on British Foreign Policy 1919-1939 (hereinafter, D.B.F.P.), Third Series, vol. I, 1938 (London: His Majesty's Stationary Office, 1949), doc. no. 39, 18-19.

4 Bentley B. Gilbert, Britain Since 1918 (New York and Evanston: Harper \& Row Publishers, 1967), 107.

${ }^{5}$ D.B.F.P., Third Series, vol. I, 1938, doc. no. 57, 32.

${ }^{6}$ Ibid., doc. no. 72, 41-42.

7 See Anthony Polonsky, Politics in Independent Poland 1921-1939. The Crisis of Constitutional Government (Oxford: Clarendon Press, 1972), 475.

8 Kenneth Bourne, D. Cameron Watt and Michael Partridge, general eds., British Documents on Foreign Affairs: Reports and Papers from the Foreign Office Confidential Print (hereinafter, B.D.F.A.), Part II: From the First to the Second World War, Series F, Europe, 1919-1939, vol. 66, Scandinavia and Baltic States, January 1938 - December 1938 (University Publications of America, 1996), doc. no. 32, 33.
} 
Lithuanian Constitution that named Vilna [today Vilnius] the capital of the country and to urgently settle all border-related disputes 9 .

Apparently, the Polish ultimatum was the result of a controversial incident that took place at the Polish-Lithuanian border, somewhere near Transninkai, on the morning of March 11, when the Lithuanian border police shot a Polish guardian. In general, this type of incidents was solved within meetings between the local authorities. Such meetings took place with this occasion as well, the commander of the Polish troops in the region admitting to the fact that the unfortunate soldier who lost his life crossed, by mistake, the border between the two states ${ }^{10}$. Even under these circumstances, the Lithuanian authorities asked Warsaw to further discuss the matter in order to find alternatives and procedures that, in the future, would prevent other such incidents happening ${ }^{11}$. As for the Polish party, the authorities in Warsaw apparently reacted disproportionately, giving the incident in Transninkai the significance of a challenge presented by Lithuania $^{12}$. Such a challenge could not be ignored, the direct consequence being the Polish ultimatum. The explanations of this gesture in historiography are diverse, but the most plausible seems to be that the Polish government tried to strengthen its position in front of Germany, which was more and more aggressive in its foreign policy, as Berlin also benefited from the "understanding" of the conciliatory Western powers 13 . Moreover, in its turn, the vicinity with the Soviet Union made the Polish leaders choose a certain expansionary policy and create influence areas to counterbalance, as much as possible, the eventual German and/or Soviet danger ${ }^{14}$.

Faced with Warsaw's ultimatum, the Lithuanians hesitated at first. Through their minister in Paris, they tried to contact the Polish

\footnotetext{
${ }_{9}$ Ibid., doc. no. 34, 35. These additional requests were included in an annex to the Polish ultimatum. See the complete text in Robert A. Vitas, „The Polish Ultimatum to Lithuania. The Dispatch of Lithuanian Minister J. Baltrušaitis in Moscow", Lituanus. Lithuanian Quarterly Journal of Arts and Sciences 31, No. 4 (Winter 1985), note no. 23, http://www.lituanus.org/1985/85_4_02.htm (April 12, 2010).

10 Robert A. Vitas, „The Polish-Lithuanian Crisis of 1938. Events Surrounding the Ultimatum", Lituanus. Lithuanian Quarterly Journal of Arts and Sciences 30, No. 2 (Summer 1984), http://www.lituanus.org/1984_2/84_2_03.htm (April 10, 2010).

11 Z. Wierzbowski, "La Pologne recouvre son independence (1914-1939)”, in Pologne 19191939. Vol. I., Vie politique et sociale (Neuchatel: Éditions de la Baconnière, 1946), 144.

12 Vitas 1984.

13 Ibid.

14 Nicolae Dascălu, Relații româno-poloneze în perioada interbelică (1919-1939) [Romanian-Polish Relations in the Interbellum Period] (Bucharest: Romanian Academy Publishing House, 1991), 67.
} 
government, proposing bilateral negotiations in a third country. Moreover, the Lithuanian diplomacy attempted to capitalize on the goodwill of the British government in order to determine the Polish to accept the offer and, in their turn, they asked for London's advice on using the mechanisms of the League of Nations to settle the differences with Poland ${ }^{15}$. The British regarded favourably to the Lithuanian offer, thinking that such an approach would lead to a peaceful and diplomatic solution to the dispute. As for the League's help, London thought that it would have been inefficient, because no action of the Assembly in Geneva could have taken place within the period mentioned in the Polish ultimatum ${ }^{16}$.

Actually, the British regarded with moderate optimism the end of the Polish-Lithuanian crisis, thinking that Lithuania had nothing to gain if it continued to interrupt de diplomatic relation with Poland, while accepting the Polish ultimatum would not have meant sacrificing any national interest. The lack of diplomatic relations and the continuous tensions could cause nothing but political frictions and poverty in the border districts, on both sides of the border. Moreover, even if the method chosen by Warsaw was not the most adequate, the Polish government wrote its ultimatum requests in a rather moderate manner, so that they would not affect Lithuania's independence, and the Polish media was asked to refrain from any comment that would disgrace Lithuania ${ }^{17}$.

In this context, the Lithuanian authorities decided to accept and satisfy Warsaw's demands, a fact regarded with quite a relief in London and Paris. However, there were also a few concerns. The Polish ultimatum and threats could very well constitute a dangerous precedent in the Baltic area. In the future, Germany could very well apply the same method to regain control over the port Memel. In this case, it was preferable, the more so, that the relations of the three Baltic states with Poland be as close as possible. The improvement of the Polish-Lithuanian relations would have been, from this point of view, extremely valuable, because it could support the British peace-making policy in Eastern Europe, as well as Warsaw's plans to build a new "cordon sanitaire" between Germany and the Soviet Union $^{18}$.

Conversely, precisely the transformation of the Polish ultimatum into a precedent favourable to Germany or other great powers with interests in

\footnotetext{
15 B.D.F.A., Part II, Series F, vol. 66, doc. no. 31, 32.

16 Ibid.

17 Ibid, doc. no. 34,36 .

18 Ibid., doc. no. 42, 47.
} 
the region raised the concern of the public opinion in Romania as well19. Allied with Poland since 1921, Romania presented a dynamics of bilateral relations that experienced, during the interwar period, an ascending tendency, with the exception of some colder phases between 1933 and 1936 caused by the concerns and suspicions raised by the closer relation between Poland and Hungary, as well as by the fact that Poland maintained a prestige policy, meant to place it at the level of the great powers and to give it a certain tutelage over the foreign orientation of other countries, Romania included $^{20}$. Thus, Bucharest appeared to be, at least officially, extremely cautious as regards the Polish ultimatum to Lithuania.

Obviously, there are plenty of explanations for this attitude adopted by the Romanian authorities. The alliance with Poland was extremely important in the strained political context in Europe, and in particular in Eastern and Central Europe, especially since the political leadership in Warsaw often underlined the fact that Poland's borders with Germany and Romania were deemed to be final ${ }^{21}$. Furthermore, this attitude is accounted for by the lack of reaction from the Western powers, as well as by the fact that the Anschluss outshone, through its significance, amplitude and possible consequences appeared to be a mere settlement of the bilateral relations between two neighbouring countries, even if the method chosen by Warsaw to get such a settlement was debatable.

Thus, Bucharest's attitude regarding the Polish-Lithuanian crisis in March 1938 or, more precisely, the lack of a definite attitude, is not arbitrary. Even the media in Bucharest presented the events rather tersely and concisely, at least in the beginning. Within the context of the publication of the Polish ultimatum, we were unable to identify in important Romanian newspapers of that period but short accounts regarding the evolution of the dispute. Very few editorials or ample articles are to be found, obviously predominated, even so, by reports on the Polish position and less about the reaction or the point of view of the authorities in Kaunas 22 .

In this context, the only visible concern appearing through the lines of press releases was the escalation of the crisis and the outbreak of an open armed conflict. In such circumstances, a possible involvement of the Soviet

\footnotetext{
19 The fact is clearly emphasized in the Romanian media of that period. See, for example, the article Relațiile dintre Polonia şi Lituania inspiră ingrijorări [The Relations between Poland and Lithuania Raise Concerns], in the newspaper Universul 55, no. 75, March 17, 1938, 15.

${ }^{20}$ Dascălu, 66.

${ }^{21}$ Ibid., 67.

22 We focused, first of all, on the accounts in the newspaper Universul, but the situation was also identical in the case of other important newspapers of the period.
} 
Union, which was rumoured to be ready to guarantee the borders of Lithuania, as well as a possible reaction of Germany, that could take advantage of the situation to support the ultimatum demands made by Warsaw, and, then, to occupy the port Memel and its surrounding area under the pretence of protecting the German minority in that area, were scenarios considered by the Romanian public opinion ${ }^{23}$.

Such scenarios seemed the more plausible as the political tensions between Warsaw and Kaunas were doubled by a quite consistent mobilization of the Polish troops at the border with Lithuania. The media in Bucharest even put forward the number of 60,000 Polish soldiers as being mobilized at the border and ready to intervene forcefully in case Lithuania refused to satisfy Warsaw's demands. Their task according to these reports was to occupy the capital Kaunas as soon as possible and to retreat only when all the Polish demands would have been satisfied ${ }^{24}$. Moreover, the state of alert of the Polish army was supplemented by many demonstrations that took place all over Poland under the quasi-official slogan "Commander, take us to Kowno!" 25 The realistic possibility of such a Polish intervention in force determined Romanian journalists to speculate about the existence of an agreement between Poland and Germany so that, together, the two countries could obtain certain territorial conquests at the expense of Lithuania. This would lead to the settlement of their own bilateral disputes, that is, Poland would have agreed to renounce the Corridor and Danzig, getting, in exchange, a new corridor towards the sea through Lithuania and the port $\mathrm{Memel}^{26}$.

The relaxation of the tension caused by the crisis and the possibility that the authorities in Kaunas might satisfy the Polish demands led to a further decrease in the interest, low as it was, shown by the public opinion in Bucharest as regards the settlement of the contentious matters between Poland and Lithuania. Practically, it was thought that, by settling this crisis, "Warsaw and Kovno would have one more diplomat and Europe one less concern", though Poland did not stand to gain all that much as a matter of prestige or position, while Lithuania lost what it did not have through this forced settlement of bilateral relations. On the other hand, in Romania it was thought that an actual improvement of the relations between Poland

\footnotetext{
23 Universul, no. 77, March 19, 1938, 13.

24 Ibid., no. 78, March 20, 1938, 12.

25 Ion Constantin, Polonia în secolul totalitarismelor 1918-1989 [Poland in the Century of Totalitarianisms 1918-1989] ( Bucureşti: Institutul Național pentru Studiul Totalitarismului, 2007), 168.

26 „Conflictul dintre Polonia şi Lituania” [The Conflict between Poland and Lithuania], Universul, no. 79, March 21, 1938, 1.
} 
and Lithuania could lead only to a consolidation of the position of the Baltic countries and to an expansion of Warsaw's influence in the region, with positive effects on the political stability of the region, within an agitated and tensed European context ${ }^{27}$.

Finally, Bucharest's distant and reserved attitude regarding the Polish-Lithuanian crisis of March 1938 was not overlooked or left unanswered by Warsaw. The Polish political leaders transmitted to Romania their gratitude for the attitude adopted and for the fact that the Romanian diplomacy understood the reasons for the Polish actions, as it did not show any opposition against them ${ }^{28}$.

Even so, the warning Warsaw received from the Western diplomacies - primarily the British one - which I could also identify in the Romanian public opinion, according to which the Polish ultimatum represented a precedent that Berlin could use in the future to expand its influence in the Baltic area to the obvious detriment of Poland, would remain valid and would come true a year later. On March 22, 1939 Lithuania signed an agreement with Germany meant to "strengthen" the relations between the two countries. Through this agreement, the Lithuanian government agreed to relinquish to Germany the sovereignty over the port city of Memel, practically an area of approximately 1,000 square miles, with a population of almost 154,000 people. Thus, Lithuania lost its only access to the sea, even if the German authorities agreed to guarantee a free zone in the port area. Moreover, no possible German compensation was provided for the huge investments made by Lithuania to modernize the port infrastructure and facilities in Memel. Even in these circumstances and despite the fact that the agreement was signed "half voluntarily, half involuntarily", the Lithuanian government declared that, generally speaking, they were pleased to sign this document with Germany ${ }^{29}$.

In this context, in spite of having received assurances on March 31, 1939 from Great Britain and France, Poland was going to be in an extremely unfavourable position. After the fall of Czechoslovakia and the new Anschluss through which the port Memel was regained, Germany controlled important territories at the northern and the southern borders of

\footnotetext{
27 Ibid.

28 See Florin Anghel, Nicolae Mareş and Dumitru Preda, eds., România-Polonia. Relații diplomatice, I, 1918-1939 [Romania-Poland. Diplomatic Relations, I, 1918-1939], Ministerul Afacerilor Externe, Direcția Arhivelor Diplomatice, Foreword by Mircea Dan Geoană, Minister of Foreign Affairs of Romania (Bucureşti: Editura Univers Enciclopedic, 2003), doc. no. 93, 192.

${ }_{29}$ Albert N. Tarulis, Soviet Policy toward the Baltic States 1918-1940 (Notre Dame: University of Notre Dame Press, 1959), 100.
} 
Poland. The irony of history is that Poland was the one to contribute, through its action in 1938 to the dissolution of the Czechoslovakian state, as well as to the weakening of the position of the Baltic States, especially that of Lithuania.

\section{References:}

A. Published documents:

Anghel, Florin, Nicolae Mareş and Dumitru Preda, eds. România-Polonia. Relații diplomatice, I, 1918-1939 [Romania-Poland. Diplomatic Relations, I, 1918-1939], Ministerul Afacerilor Externe, Direcția Arhivelor Diplomatice, Foreword by Mircea Dan Geoană, Minister of Foreign Affairs of Romania. Bucureşti: Editura Univers Enciclopedic, 2003.

Bourne, Kenneth, D. Cameron Watt, and Michael Partridge, general eds. British Documents on Foreign Affairs: Reports and Papers from the Foreign Office Confidential Print. Part II: From the First to the Second World War, Series F, Europe, 1919-1939. Vol. 66, Scandinavia and Baltic States, January 1938 - December 1938. University Publications of America, 1996.

Woodward, E.L., and Rohan Butler, eds. Documents on British Foreign Policy 19191939. Third Series. Vol. I, 1938. London: His Majesty's Stationary Office, 1949.

B. Newspapers:

Universul: no. 75, March 17, 1938; no. 77, March 19, 1938; no. 78, March 20, 1938; no. 79, March 21, 1938.

C. Books and articles:

Bold, Emilian and Ioan Ciupercă. Europa în derivă (1918-1940). Din istoria relatitilor internationale [Europe Adrift (1918-1940). From the History of International Relations]. Iaşi: Demiurg Publishing House, 2001.

Constantin, Ion. Polonia in secolul totalitarismelor 1918-1989 [Poland in the Century of Totalitarianisms 1918-1989]. Bucureşti: Institutul Național pentru Studiul Totalitarismului, 2007.

Dascălu, Nicolae Relații româno-poloneze în perioada interbelică (1919-1939) [Romanian-Polish Relations in the Interbellum Period] (Bucureşti: Editura Academiei, 1991).

Gilbert, Bentley B. Britain Since 1918. New York and Evanston: Harper \& Row Publishers, 1967.

Kissinger, Henry. Diplomația [Diplomacy], Translated by Mircea Ştefancu and Radu Paraschivescu. Bucharest: All Publishing House, 1998.

Polonsky, Anthony. Politics in Independent Poland 1921-1939. The Crisis of Constitutional Government. Oxford: Clarendon Press, 1972.

Tarulis, Albert N. Soviet Policy toward the Baltic States 1918-1940. Notre Dame: University of Notre Dame Press, 1959. 
Vitas, Robert A. „The Polish Ultimatum to Lithuania. The Dispatch of Lithuanian Minister J. Baltrušaitis in Moscow". Lituanus. Lithuanian Quarterly Journal of Arts and Sciences 31, No. 4 (Winter 1985). http://www.lituanus.org/1985/85_4_02.htm (accessed on April 12, 2010).

Vitas, Robert A. „The Polish-Lithuanian Crisis of 1938. Events Surrounding the Ultimatum". Lituanus. Lithuanian Quarterly Journal of Arts and Sciences 30, No. 2 (Summer 1984). http://www.lituanus.org/1984_2/84_2_03.htm (accessed on April 10, 2010).

Wierzbowski, Z. „La Pologne recouvre son independence (1914-1939)”. In Pologne 1919-1939. Vol. I., Vie politique et sociale. Neuchatel: Éditions de la Baconnière, 1946. 